\title{
ANALYZING THE EFFECT OF THE 500 BIGGEST CENTRAL EUROPEAN COMPANIES ON SPATIAL STRUGTURE
}

\author{
Zoltán NAGY* ${ }^{\text {a* }}$ Géza TÓTH ${ }^{\mathrm{b}}$, Tekla Sebestyén SZÉP \\ a),b,c) Institute of World and Regional Economics, Faculty of Economics, \\ University of Miskolc, Miskolc, Hungary
}

Please cite this article as:

Article History:

Nagy, Z., Tóth, G. and Szép, T.S., 2018. Analyzing the Received: 19 September 2017 effect of the 500 biggest Central European companies Accepted: 11 November 2017 on spatial structure. Review of Economic Studies and Research Virgil Madgearu, 11(1), pp.55-74.

doi: 10.24193/RVM.2018.11.21.

Abstract: Many theoretical and practical works deal with the spatial structure of Europe. This article gives an overview of these papers focusing on Central and Eastern Europe. Our goal is to contribute to understanding the Central and Eastern European spatial structure through a new methodological approach. The research question is how the biggest companies and cities which host the biggest corporate headquarters affect the economic spatial structure of Central and Eastern Europe. Is there any overlap with the former spatial structure models? To study these research questions many methods are applied, such as the Eastern European Command and Control Index, a kindly novel approach to measure the competitiveness of cities and the spatial cluster analysis as well. This research draws the attention to the increasing importance of the capital cities and to the fact that the New Banana model covers the largest area in the region.

Key words: spatial structure; Central and Eastern Europe; spatial cluster analysis; economic potential; command and control function

JEL Classification: R12; N14; F23

(C) 2018 Alma Mater Publishing House. All rights reserved.

* Corresponding author. E-mail address: nagy.zoltan@uni-miskolc.hu. 


\section{References}

1. Beaverstock, J.V., Smith, R.G. and Taylor, P.J., 1999. A Roster of World Cities. Cities, 16(6), pp.445-458.

2. Bernek, Á., 2000. A globális világ “új gazdaságföldrajza”. Tér és Társadalom, 4, pp.87-107.

3. BBSR, 2011. Metropolitan areas in Europe. Federal Institute for Research on Building, Urban Affairs and Spatial Development (BBSR) wthin the Federal Office for Building and Regional Planning, Bonn, BBSR-Online-Publikation, no. 01/2011.

4. Csomós, G., 2011. A közép-európai régió nagyvárosainak gazdaságirányító szerepe. Tér és Társadalom, 25(3), pp.129-140.

5. Csomós, G., Derudder, B., 2006. European Cities as Command and Control Centres. European urban and regional studies, 21(3), pp.345-352.

6. Csomós, G., 2013. A világgazdaság irányító és ellenőrző központjai 2012-ben. Tér és társadalom, 27(3), pp.93-108.

7. Deloitte, 2016. Central Europe Top 500. https://www2.deloitte. $\mathrm{com} / \mathrm{global} / \mathrm{en} / \mathrm{pages} /$ about-deloitte/articles/central-europetop500.html.

8. Deloitte, 2008. Central Europe Top 500. https://www2.deloitte. $\mathrm{com} / \mathrm{hu} / \mathrm{hu} . \mathrm{html}$.

9. Dicken, P., 2007. Global Shift. Mapping the Changing Contours of the World Economy. London: SAGE Publications.

10. Dommergues, P., 1992. The Strategies for International and Interregional Cooperation. Ekistics, 352(3), pp.7-12.

11. Egri, Z. and Litauszky, B., 2012. Térszerkezeti sajátosságok KözépKelet-Európában. http://www.mrtt.hu/vandorgyulesek/2012/2/ egri.ppt [Accessed November 2012].

12. Enyedi, G., 2003. Városi világ - városfejlődés a globalizáció korában. Pécs: Pécsi Tudományegyetem.

13. Enyedi, G., 2012. A városi világ. Budapest: Akadémiai Kiadó.

14. ESDP, 1999. European Spatial Development Perspective (Adopted by the European Council of EU Ministers Responsible for Spatial Planning, in Potsdam, 10-11/05/99.) European Comission, Brussels.

15. ESPON, 2005. Potentials for polycentric development in Europe. Luxemburg: ESPON. 
Nagy, Tóth, SzéP, Analyzing ... Central European Companies ...

16. ESPON, 2012. POLYCE Metropolisation and Polycentric Development in Central Europe. Luxemburg: EU ERDF, ESPON.

17. Faludi, A., 2005. Polycentric territorial cohesion policy. In: A. Faludi (ed.) Territorial Cohesion: An Unidentified political objective (Special Issue). Town Planning Review, 76(1), pp.107-118.

18. Gorzelak, G., 2012. The Regional Dimension of Transformation in Central Europe. London: Routledge.

19. Houston, D.B., 1967. The shift and share analysis of regional growth: a critique. Southern Economic Journal, 33(4), pp.577-581.

20. Illés, I., Somlyódyné Pfeil, E., 2005. Változási trendek az Unió Regionális politikájában - magyar tanulságok MTA RKK Pécs.

21. Kincses, Á., Nagy, Z., Tóth, G., 2013. The spatial structures of Europe: prostorske strukture v evropi. Acta Geographica Slovenica, 53(1), pp.43-70.

22. Kunzmann, K.R. and Wegener, M., 1991. The pattern of urbanization in Europe. Ekistics, 58, pp.282-291.

23. Kunzmann, K.R., 1992. Zur Entwicklung der Stadtsysteme in Europa. Wien Mitteilungen der Österreichischen Gesellschaft, 134, pp.25-50.

24. Kunzmann, K.R., 1996. Euro-megalopolis or Themepark Europe? Scenarios for European spatial development. International Planning Studies, 1(2), pp.143-163.

25. Leibenath, M., Hahn, A. and Knippschild, R., 2007. Der „Mitteleuropäische Kristall“ - zwischen „Blauer Banane“ und „osteuropäischem Pentagon“. Perspektiven der neuen zwischenstaatlichen deutsch-tschechischen Arbeitsgruppe für Raumentwicklung Angewandte Geographie, 31, pp.36-40.

26. Lengyel, I. and Rechnitzer, J., 2000. A városok versenyképességéról. In: G. Horváth and J. Rechnitzer (eds.): Magyarország területi szerkezete és folyamatai az ezredfordulón. Pécs: MTA RKK, pp. 130-152.

27. Lux, G., 2012. A gazdaság szerepe a városi térségek fejlesztésében: A globális kihívásoktól a fejlesztéspolitikáig. In E. Somlyódyné Pfeil, ed. 2012. Az agglomerációk intézményesítésének sajátos kérdései: Három magyar nagyvárosi térség az átalakuló térben. Pécs: Publikon Kiadó, pp.69-94.

28. Meer, L. van der, 1998. Red octopus. In W. Blaas, A new perspective for European spatial development policies, Aldershot (Ashgate), pp.9-19. 
29. Pénzes, J. and Fekete, J., 2014. Transformation of the spatial structure in the Visegrad countries in the light of the location of peripherial areas. In Z. Radics and J. Pénzes, eds. 2014. Spatialeconomic cohesion and competitiveness in the context of tourism, Debrecen: Didakt Kiadó, pp.11-24.

30. Raźniak, P., Dorocki, S., Winiarczyk-Raźniak, A., 2018. Eastern European cities as command and control centers in a time of economic crisis. Acta geographica Slovenica, 57(2), pp.103-110. https://doi.org/10.3986/AGS.3124.

31. Sassen, S., 1991. The Global City: New York, London, Tokyo. Princeton: Princeton University Press.

32. SIC, 2006. Sustrain implement corridor. Long factbook http://195.230.172.167/cms_sic/upload/pdf/o61010_SIC_ LongFactbook.pdf [Accessed: October 2012].

33. Stevens, B.H., Craig, L.M., 1980. A critical review of the literature on shift-share as a forecasting technique. Journal of Regional Science, 20(4), pp.419-437.

34. Stewart, J.Q., 1947. Empirical mathematical rules concerning the distribution and equilibrium of population. Geography Review, 37(3), pp.461-485.

35. Szabó, P., 2015. Régió és térszerkezet az elmélettől a területpolitikáig. Budapest: ELTE Eötvös Kiadó.

36. Szabó, P. and Farkas, M., 2014. Kelet-Közép-Európa térszerkezeti képe. Tér és Társadalom, 28(2), pp.67-86.

37. Szendi, D., 2013. The convergence process and the effects of the economic crisis in Central-Eastern Europe, Romanian Review of Regional Studies: Journal of the Centre for Regional Geography, IX(1), pp.79-84. 